\title{
SPATIAL DISTRIBUTION PATTERN OF VILLAGE DEVELOPMENT INDEX IN KARAWANG REGENCY USING SPATIAL AUTOCORRELATION APPROACH
}

\author{
Alfin Murtadho', Andrea Emma Pravitasari², Khursatul Munibah3, Ernan Rustiadi4 \\ ${ }^{1}$ Regional Planning Science, Graduate School of IPB, IPB University, Jl. Meranti, IPB Darmaga Campus, Bogor, West Java, Indonesia, \\ 16680 \\ 2,3,4 Department of Soil Science and Land Resource, Faculty of Agriculture, IPB University, Jl. Meranti, IPB Darmaga Campus, Bogor, \\ West Java, Indonesia, 16680
}

Article Info:

- Received: $9^{\text {th }}$ August 2019

- Available Online: $30^{\text {th }}$ June 2020

\begin{abstract}
Jabodetabek and Greater Bandung Metropolitan areas experiencing the phenomenon of urban expansion which has caused both metropolitan areas to be more connected and become a mega-urban area by a corridor through a conurbation process. Karawang Regency is part of the region in the Jakarta-Bandung corridor. The increasing number of a population in the region will encourage the addition of number and types of public facilities. Objectives of this study were to analyze the regional development and spatial distribution pattern of the Village Development Index/Indeks Perkembangan Desa (IPD) in Karawang Regency. Regional development was analyzed using scalogram analysis, while spatial distribution pattern of the IPD was analyzed using Global and Local Moran Index. IPD values resulted from regional development analysis are divided into 3 interval classifications, low, moderate, and high classifications. Results shows the distribution of the IPD in 2014 has increased from 2003. In 2003, there are 12 villages with high and 47 village with moderate classifications, while in 2014, there are 21 villages with high and 82 villages with moderate classifications. Analysis of spatial distribution pattern of IPD values from 2003 and 2014 shows the clustered distribution patterns in some Sub-districts. Villages that have high IPD values in 2003 tend to be villages in Karawang Barat and Karawang Timur Sub-districts. Whereas villages that had high IPD values in 2014 tended to be villages in Karawang Barat, Timur Karawang, and Telukjambe Timur Sub-districts.
\end{abstract}

Kata kunci: Jakarta-Bandung corridor, public facilities, regional development

\section{INTRODUCTION}

Regions can be interpreted as a unitary system consisting of parts that have relevance, dependence, and interact with each other and cannot be separated (Rustiadi et al., 2018). The entire Jakarta area has a dependency and interacts with the Bogor, Depok, Tangerang, and Bekasi area so that the Jabodetabek Metropolitan Area is formed. The same thing happened with the area of Bandung municipality that has a dependency and interacts with the Cimahi municipality, Bandung Regency, and West Bandung Regency so that the Greater Bandung Metropolitan Area is formed. Jabodetabek and Greater Bandung metropolitan areas experience the phenomenon of urban expansion caused by the process of urbanization and suburbanization. This urban expansion is characterized by an increase in built-up areas that spread out from the city center to the outskirts of the city to cause an increase in economic development and urban activities (Pravitasari et al., 2015). This phenomenon of urban expansion has caused the Jabodetabek and Greater Bandung metropolitan area to become increasingly connected to become a mega-urban area by a corridor. This mega-urban area is called Jakarta-Bandung Mega-Urban Region or JBMUR (Dorodjatoen, 2009). The formation of the JBMUR mega-urban area is caused by the conurbation process. Conurbation according to Minister of Public Works Regulation No. 494 of 2005 concerning Policy and National Strategy of Urban Development, is the process of the occurrence of urban physical development which results in the joining of a metropolitan area with surrounding areas so that a larger metropolitan area is formed. 
The Jakarta-Bandung conurbation process is characterized by an increase in population growth, activity in various sectors, and the development of built-up areas that are connected with a network road or corridors in these two metropolitan areas like Bogor-Puncak-Cianjur-Bandung network road and Cipularang toll road (Saifullah et al., 2017). Karawang Regency is part of the area in the Jakarta-Bandung corridor. The corridor area is an area on the path that connects two major cities due to the conurbation process. Areas along the road connecting the two major cities were not identified as areas that had developed physically. Over time, the corridor area will experience spatial, economic, social and cultural transformation so that it tends to undergo regional structural transformation (Giyarsih, 2012) where the regional structural transformation that occurs is the regional structure transformation of rural type areas into urban type areas. The process of regional structure transformation into urban type areas will have an effect on increasing land demand due to the increase in population growth both in fertility, mortality, and migration (Abror et al., 2016). The increase in the need for land causes the process of land conversion, especially the conversion of vegetated land areas into built-up areas (Pravitasari et al., 2018).

The increasing number of a population in an area will encourage the addition number and types of public facilities due to the increasing need for both regional infrastructure and facilities so that regional developments occur. Regional development will have an impact on increasing pressure on land and land use changes as a result of increasing population, social activities, and economic activities of the community (Sitorus, 2017). One of the problems due to the regional development is competition in land use which is driven by increased in land resource needs such as food needs that require agricultural land to produce, as well as the needs of settlements and public service facilities that require built-up areas (Sitorus et al., 2011). In such conditions, agricultural land has a great opportunity to be converted into built-up areas.

The increase in population and socio-economic activities of the people in the Jakarta-Bandung corridor area became an important issue concerning the regional development of the Karawang Regency. Based on the background mentioned, a research question arises "how is the spatial distribution pattern of regional development in Karawang Regency as a part of the area in the Jakarta-Bandung corridor?". Then, the objectives of this study were to analyze the regional development and spatial distribution pattern of the Village Development Index/Indeks Perkembangan Desa (IPD) in Karawang Regency.

\section{DATA AND METHODS}

\subsection{Study area}

The location of this study is in Karawang Regency, West Java Province that consist of 30 sub-districts and 302 villages. Geographically, Karawang Regency located between $107^{\circ} 02^{\prime}-107^{\circ} 40^{\prime}$ East Longitude \& $5^{\circ} 56^{\prime}$ $-6^{\circ} 34^{\prime}$ South Latitude, which borders with Java Sea in the North, Subang Regency in the East, Purwakarta, Cianjur, and Bogor Regency in the South, also Bogor and Bekasi Regency in the West [Figure 1]. The population of Karawang Regency in 2015 has reached 2,059,742 people with a population growth rate of 4.61\%. In terms of the economy, there are 3 sectors that have the largest contribution in the formation of Gross Domestic Regional Products in Karawang Regency in 2015. The biggest is the permanent manufacturing sector which contributed $70.99 \%$, followed later by the trade and agriculture sectors, each of which contributed 10.02\% and 4.16\% (Karawang Regency Medium-term Development Plan/RPJMD 20162021).

Karawang Regency is part of the area in the Jakarta-Bandung corridor that tends to experience regional structure transformation of rural type areas into urban type areas as an impact of the JBMUR conurbation process. The transformation of rural type areas into urban type areas will cause an increase in public needs for settlement, infrastructure, and public facilities, so that the region will experience a regional development. Karawang Regency is one area that has fertile land in West Java, so most of its land is used for agriculture. Karawang Regency is one of the "national rice barns" areas where Karawang Regency is directed as a wetland agriculture area which is one of the regencies with the largest rice production in West Java (West Java Province Spatial Plan/RTRW of 2009-2029). Pressure from public needs for settlement, infrastructure, and public facilities is expected to trigger the development of Karawang Regency towards 
Murtadho, Pravitasari, Munibah, Rustiadi/ Jurnal Pembangunan Wilayah dan Kota, Vol.16, No.2, 2020, 102-111 Doi: https://doi.org/10.14710/pwk.v16i2.24883

industrialization which will depress land use for agriculture, especially paddy fields and will impact the rice production in West Java.

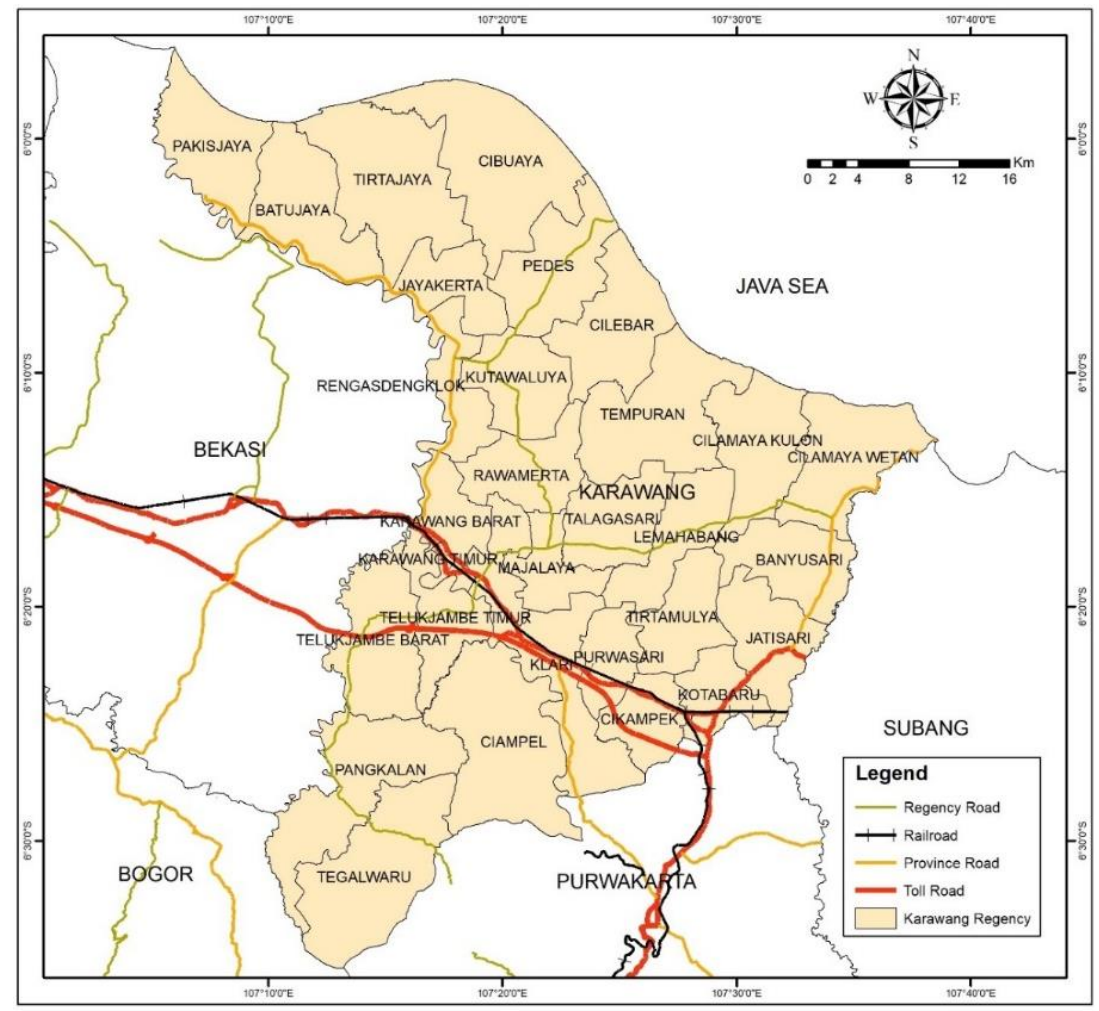

Figure 1. Research location map

\subsection{Data}

This study is using secondary data of Karawang Regency administrative maps in 2010 that sourced from Central Agency on Statistics (BPS) and numbers of public facility data that were collected from PODES (Village Potential Statistics) provided by the Central Agency on Statistics (BPS) for the years 2003 and 2014. The unit of analysis in this study is a village level.

\subsection{Methods}

\section{Regional Development Analysis}

Regional development analysis is done by using a scalogram method which serves to see an overview of the level of development in an area administratively based on accessibility distance data, the number and type of public facilities data, and the population data obtained from the Village Potential Statistics data (PODES). The variables in this analysis are divided based on accessibility data, educational facilities, health facilities, and economic facilities which listed in Table 1.

The level of regional development of a region is determined by a level of hierarchy based on the value of the Village Development Index/Indeks Perkembangan Desa (IPD). The stages used in determining the regional development using scalogram analysis are as follows (Panuju \& Rustiadi 2010):

a. rationalize distance data (accessibility). Distance data is converted by the formula: $: y=1 / x_{i i}$, where $y$ is the new variable and $x_{i j}$ is $j$ distance data in the i region. The undefined $y$ value $(x i j=0)$ will be calculated by the equation: $y=x_{i j}$ (maximum value) plus the standard deviation of $j$ distance.

b. weighting the distance data and facilities data by distance data and $j$ facilities data divided by distance weights and $j$ facilities, where weights data and $j$ facilities = total of distance data and $j$ facilities data divided by the number of regions that have distance data and $j$ facilities. 
c. standardize data that carried out on the new variables from distance data and facilities data (weighted) using formulas:

$$
y i j=\frac{X i j-(\operatorname{Min} X j)}{S j}
$$

where:

$y_{i j} \quad$ : new variable from $i$-region and type of facilities and $j$-distance

$x_{i j} \quad:$ sum of facilities in $i$-region and type of facilities or $j$-distance

$\operatorname{Min}\left(x_{j}\right) \quad$ : minimum value for type of facilities or $j$-distance

$\mathrm{S}_{\mathrm{j}} \quad$ : standard deviations for type of facilities or $j$-distance

d. calculating village development index data (IPD) that determined by calculating sum of distance and facilities standardized data in every unit village. Formulas for determining IPD values are as follows:

$$
I P D_{\mathrm{j}}=\sum_{i=1}^{p} Y_{\mathrm{ij}}
$$

where:

IPD : village development index;

$Y_{i j} \quad$ : sum of i-facility type in j-region

\begin{tabular}{|c|c|}
\hline Type & Variable Name \\
\hline \multirow[t]{3}{*}{ Accessibility } & Distance from the village office to the sub-district office in charge \\
\hline & Distance from the village office to the regency/municipality office in charge \\
\hline & Distance from the village office to the other regency/municipality office in charge \\
\hline \multirow[t]{9}{*}{ Educational Facilities } & Kindergarten \\
\hline & Elementary school/Islamic elementary school \\
\hline & Junior high school/Islamic junior high school \\
\hline & Senior high school/Islamic senior high school \\
\hline & Vocational school \\
\hline & Academy/University \\
\hline & Special School \\
\hline & Private Islam school/Private Madrasah \\
\hline & Seminary \\
\hline \multirow[t]{10}{*}{ Health Facilities } & Hospital \\
\hline & Maternity Hospital \\
\hline & Health center \\
\hline & Auxiliary health center \\
\hline & Polyclinic/medical center \\
\hline & doctor's place of practice \\
\hline & Midwife practice \\
\hline & Village maternity \\
\hline & Maternal and child health center \\
\hline & Pharmacy \\
\hline \multirow[t]{9}{*}{ Economic Facilities } & Supermarkets/Convenience stores \\
\hline & Shop/Stall/Kiosk \\
\hline & Restaurant/Food shop beverage \\
\hline & Hotel/Lodging \\
\hline & Leather craft industry \\
\hline & Wood craft industry \\
\hline & Metal craft industry \\
\hline & Wicker/Pottery/Ceramic craft industry \\
\hline & Fabric/Woven craft industry \\
\hline
\end{tabular}

Table 1. List of variables that used in scalogram analysis (Village Potential data /PODES) 


\begin{tabular}{ll}
\hline Type & Variable Name \\
\hline Food craft industry \\
Commercial banks \\
People's credit bank \\
Village unit cooperative (KUD) \\
\hline
\end{tabular}

\section{Global Moran Index}

The measurement of spatial autocorrelation for spatial data globally can be calculated using the Moran's Index (Moran's I) method which can be calculated using ArcGIS software. This method can be used to detect spatial randomness. This spatial randomness indicates patterns that may be clustered, dispersed, or random. According to Anselin (1995), the calculation of spatial autocorrelation with the Moran Index method can be done by:

$$
\begin{aligned}
& I=\frac{n \sum_{i=1}^{n} \sum_{j=1}^{n} w_{i j}^{*}\left(x_{j}-\bar{x}\right)\left(x_{j}-\bar{x}\right)}{S_{0} \sum_{i=1}^{n}\left(x_{i}-\bar{x}\right)} \\
& S_{0}=\sum_{i=1}^{n} \sum_{j=1}^{n} w_{i j}^{*}
\end{aligned}
$$

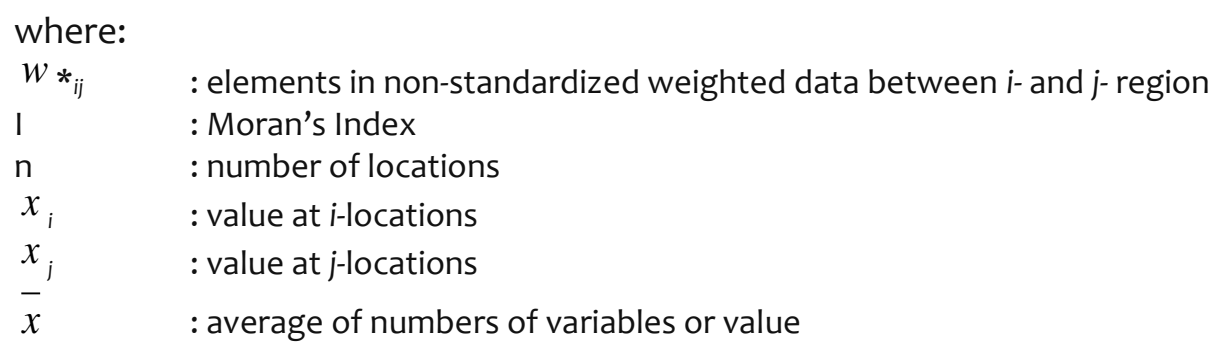

To identify the presence of spatial autocorrelation, Moran Index significance test was carried out where there was autocorrelation at the a significance level if $Z(I)>Z_{1-\alpha}$ with $Z_{1-\alpha}$ is (1-a) quantile from a standard normal distribution (Anselin, 1995). If there is spatial autocorrelation, the range of values from the Index are $-1 \leq I \leq 1$. Range of values $-1 \leq I<0$ shows there are negative spatial autocorrelations, while the values in range $0<\mathrm{I} \leq 1$ shows there are positive spatial autocorrelations. If the value of Moran Index is zero indicates non groupping values.

\section{Local Moran Index}

The measurement of spatial autocorrelation for spatial data locally can be calculated using the Local Moran's Index method or commonly called the LISA (Local Indicator of Spatial Autocorrelation) approach which can be calculated using GeoDA software (Anselin, 2005). LISA is used to identify how the relations between a location of observation locally to another observation location. According to Wong and Lee (2005), the calculation of spatial autocorrelation with the Local Moran Index method can be done in a way:

$$
I_{i}=\frac{y_{i}-\bar{y}}{s t d} \sum_{j} w_{i j} \frac{y_{j}-\bar{y}}{s t d}
$$

where:

$$
\begin{array}{cl}
\mathrm{I}_{i} & \text { : LISA Index } \\
y_{i} & \text { : value at i-locations } \\
y_{j} & \text { : value at } j \text {-locations } \\
\text { std } & : \text { standard deviations value } \\
w_{i j} & : \text { spatial weighted matrix }
\end{array}
$$


Murtadho, Pravitasari, Munibah, Rustiadi/ Jurnal Pembangunan Wilayah dan Kota, Vol.16, No.2, 2020, 102-111 Doi: https://doi.org/10.14710/pwk.v16i2.24883

\section{RESULT AND DISCUSSION}

\subsection{Regional Development}

Panuju \& Rustiadi (2010) define the development of a region can be understood from the increasing number of regional components and their spread (spatial reach) or the activities of a wider spread of regional components. It can be said that a region will develop if the number of types of activities in the region increases, for example, an alternative source of income for the people in a region increase so that the economic activity in the region also increases. So, it can be said that regions with more types of activities are more developed regions. The development of a region is determined by the level of the development index, where the higher the index value, the more developed the region is. Conversely, the lower the index value, the more developed a region is. The village development index is obtained by conducting a scalogram analysis which is an analytical tool used to determine the ability of a region in order to provide services to the community. The service referred to in this case is the availability of public facilities in the area (Nainggolan, 2005).

Karawang Regency has about 309 villages from 30 sub-districts. Regional development from the scalogram analysis can be spatially seen in Figure 2. The Regional Development (IPD) results showed the distribution of IPD values in the range 2 to 98 which were divided into 3 interval classifications, IPD values ranging from 2-19 as low classifications, 19.1-40 as moderate classifications, and 40.1-98 as high classifications. In 2003, there are 12 villages with high classifications, 47 villages with moderate classifications, and 250 villages with low classifications. In 2014, there are 21 villages with high classifications, 82 villages with moderate classifications, and 206 villages with low classifications.

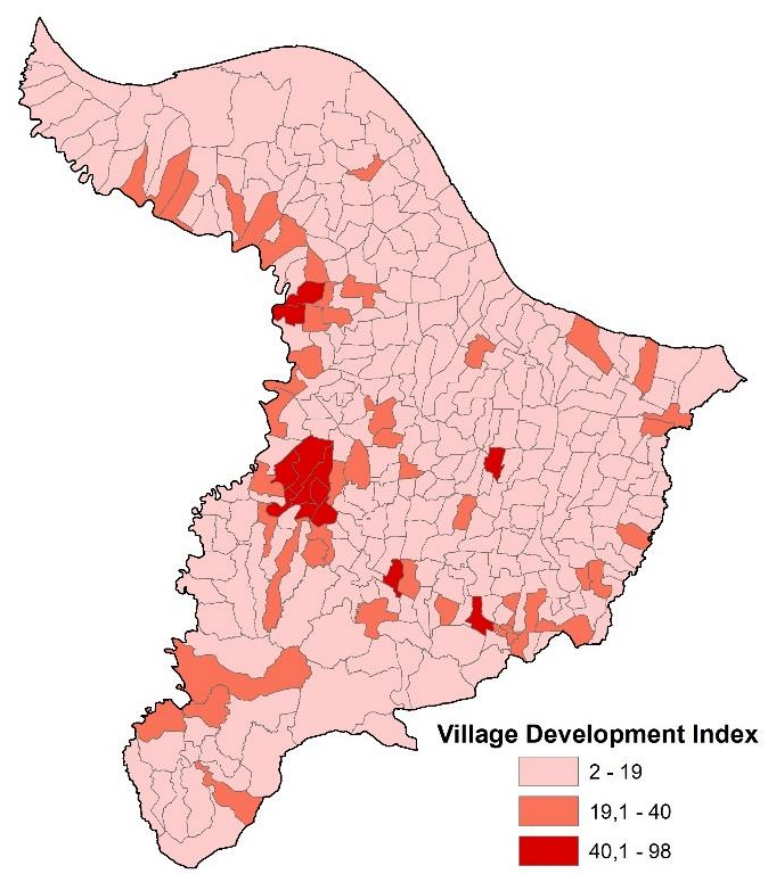

a

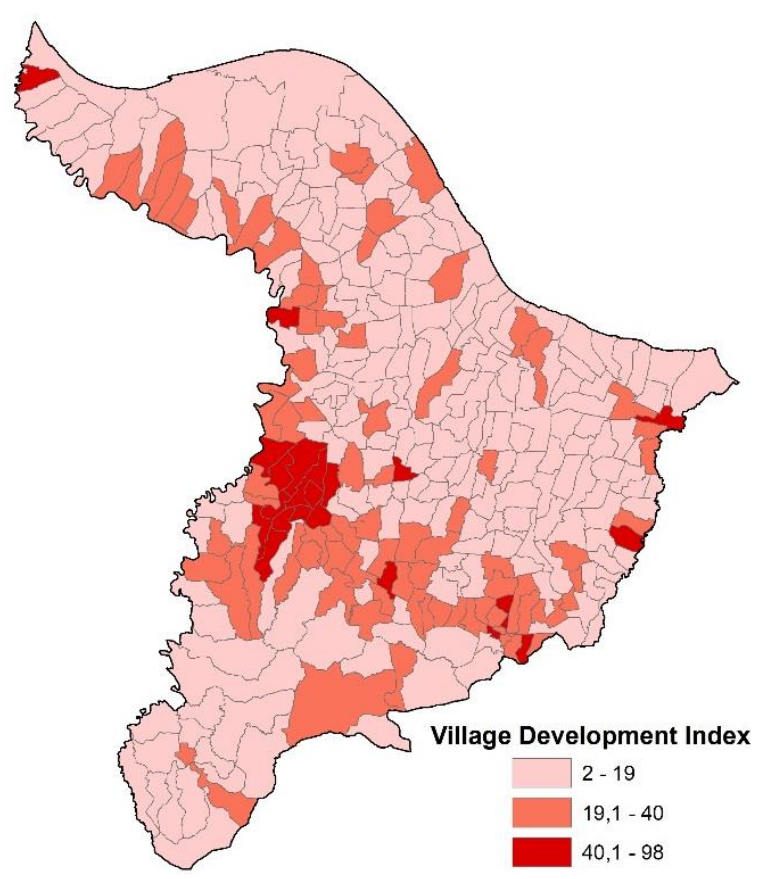

b

Figure 2. Village development index in Karawang Regency in (a) 2003 and (b) 2014

Villages that have high IPD values in 2003 tend to be villages in Karawang Barat and Karawang Timur Sub-districts. Whereas villages that had high IPD values in 2014 tended to be villages in Karawang Barat, Karawang Timur, and Telukjambe Timur Sub-districts. Villages near the network roads that connecting Jakarta-Bandung experienced an increase in the value of IPD from being dominated by low classified IPD values in 2003 to moderate and high classifications IPD values in 2014. This indicates that the regional 
development in Karawang Regency tends to be high in areas located near the network roads that connecting Jakarta-Bandung as happened in Purwakarta Regency (Murtadho et al., 2018) where Karawang and Purwakarta Regency is part of the region in the Jakarta Bandung Mega Urban Region corridors. According to Giyarsih (2012) in the regions of intercity corridors, the accessibility level is the most powerful factor influencing population activities which will eventually accelerate the pace of regional development. The increasing rate of regional development will lead to increasing land use conversion, especially on vegetated lands that conversed to built-up areas due to the massive construction of both regional infrastructure and facilities.

\subsection{Spatial Autocorrelation}

Spatial autocorrelation is the correlation between variables with themselves based on space or can also be interpreted as a measure of the similarity of objects in a space (distance, time and region). Spatial autocorrelation shows the influence of an attribute value in a location with attribute values in another location (Fotheringham \& Rogerson, 1993). Determining the proximity relation between locations can be expressed in a contiguity matrix or spatial weighting matrix (Yuriantari et al., 2017). The contiguity matrix is a matrix that describes the relation between regions or matrices that describe the proximity relation between regions. This contiguity matrix has a general grid of proximity/ neighborhood which can be defined in several ways, namely rock contiguity, bishop contiguity, and queen contiguity criterion. In this study, the queen contiguity matrix is used. The queen contiguity criterion determines neighboring units as those that have any point in common, including both common boundaries and common corners (Anselin, 2005).

In this study, we employed spatial autocorrelation analysis using Global Moran Index and Local Moran Index/LISA to analyze spatial distribution pattern of IPD in Karawang Regency. The results of the Global Moran Index analysis using ArcGIS software can be seen in Figure 3. The results of the Global Moran Index analysis for the IPD in Karawang Regency in 2003 and 2014 show that the spatial pattern is Clustered in an area. This result is significance because the $Z(I)$ value that is 10.66 already more than Z1- $a$ value (Wuryandari et al. 2014) that is 1.64, so there is a spatial autocorrelation of IPD values in Karawang Regency in 2003 and 2014.

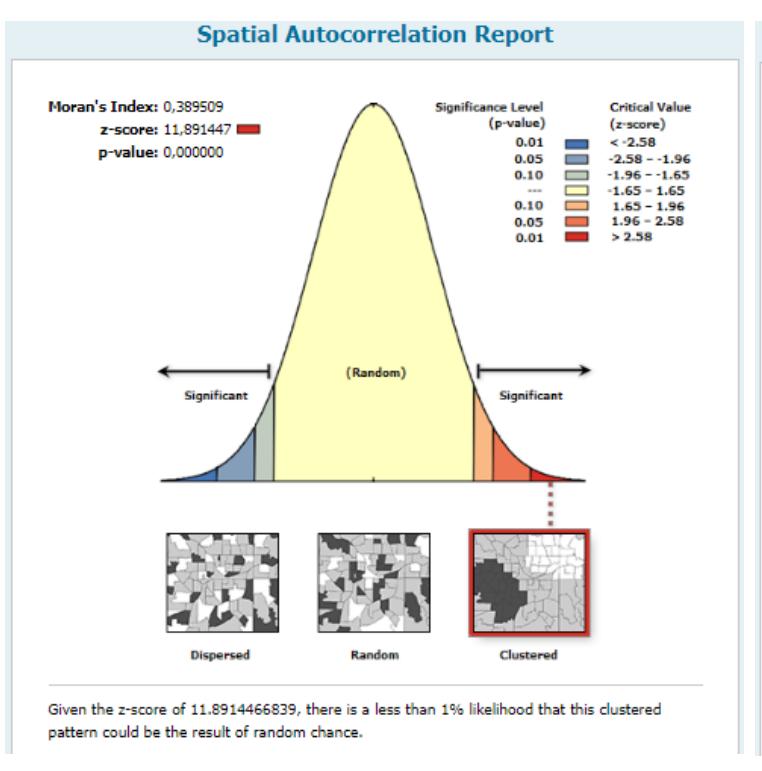

a

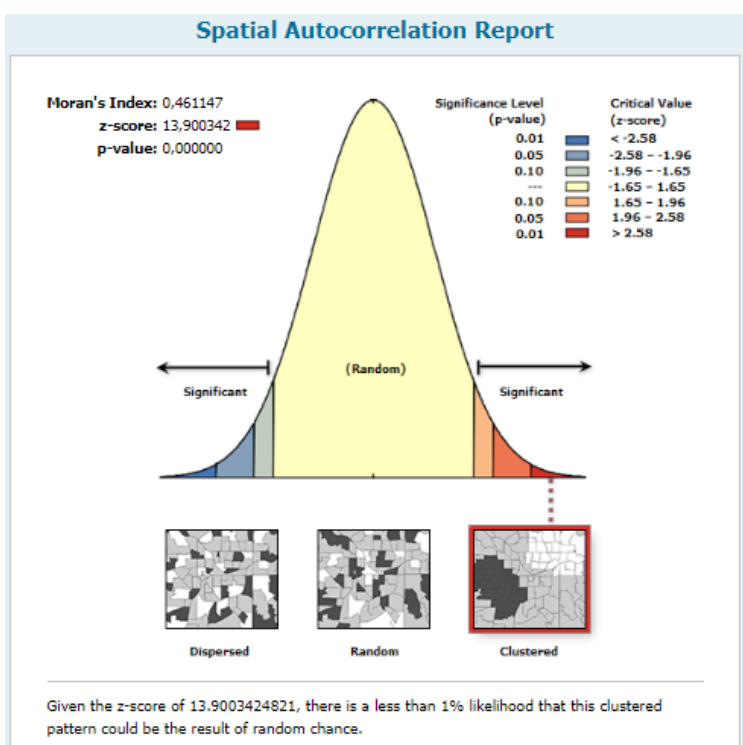

$\mathrm{b}$

Figure 3. Result of Global Moran Index of IPD values in (a) 2003 (b) 2014

In this study, we identified spatial distribution pattern of IPD with Local Moran Index using GeoDA software. The Local Moran Index implemented in GeoDa is a special case of a LISA statistic where the 
average of the Local Moran Index is proportional to the Global Moran Index value (Pravitasari et al., 2014). Spatial distribution pattern of IPD will appear when the spatial association (SA) of its data has a positive value (High-High or Low-Low type) or negative value (High-Low or Low-High type). Positive SA exist when high values correlate with high neighboring values or when low values correlate with low neighboring values, while negative SA exists when high values correlate with low neighboring values or when low values correlate with high neighboring values (Anselin, 1995).

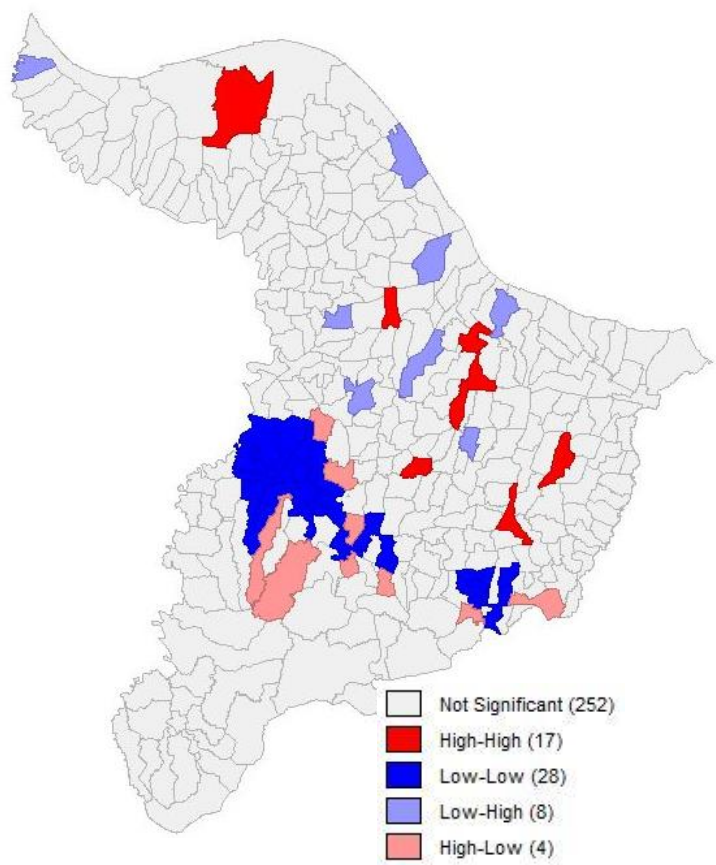

a

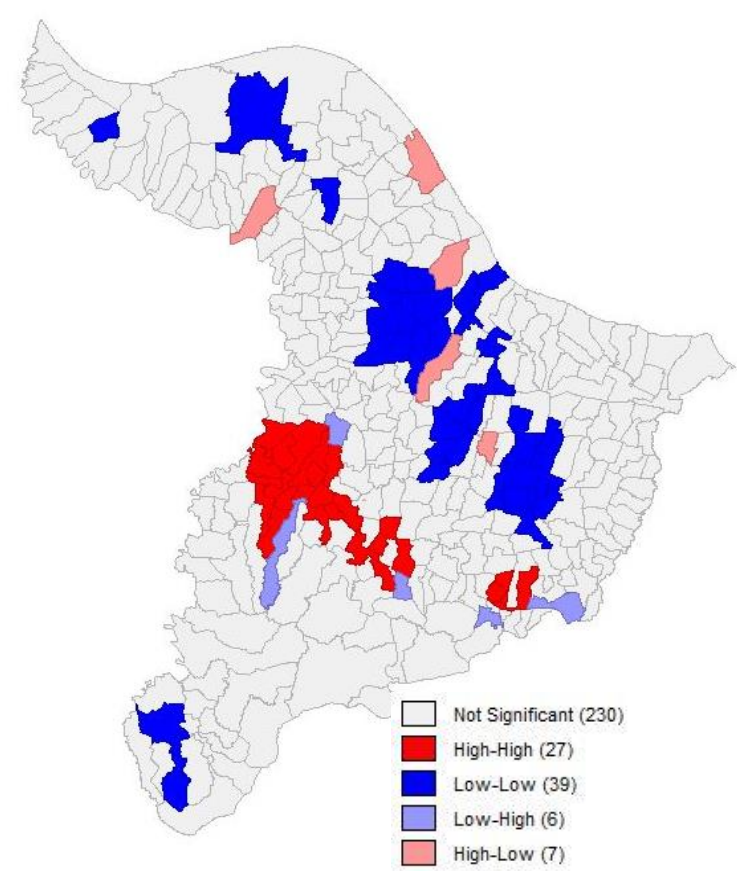

b

Figure 4. LISA cluster map of IPD values in (a) 2003 \& (b) 2014

Result of LISA analysis in Figure 4 shows that the IPD values in 2003 had a spatial distribution pattern that locally clustered in villages in the Karawang Barat, Karawang Timur, and Telukjambe Timur Sub-districts as well as villages near the network roads that connecting Jakarta-Bandung metropolitan areas with LL (Low-Low) type values. This LL type value indicates that the IPD value in the village is low and surrounded by villages that have low IPD values as well. In 2014, the IPD values had a spatial distribution pattern that locally clustered in villages in the same Sub-districts as 2003 but with $\mathrm{HH}$ (High-High) type values. This $\mathrm{HH}$ type value indicates that the IPD value in the village is high and surrounded by villages that have high IPD values as well. There is an increase in the value of LISA from 2003 to 2014 that showed the villages experienced an increase in the IPD values and had more spatial autocorrelation with each other. The LISA value in 2014 also shows that villages in the northern part of Karawang Regency experienced a decline in LISA value which initially HH type value in 2003 to become LL type value in 2014, however, more and more villages in the northern part of Karawang Regency had a spatial autocorrelation.

This result shows that the regional development in Karawang Regency in 2003-2014 is centered in the middle part of Karawang Regency area especially near the network roads that connecting Jakarta-Bandung metropolitan areas. If this continues, there will be economic imbalances between the central part of Karawang Regency while other areas in the north and south of Karawang Regency which are still dominated by agricultural activities. The middle part area near the network roads that connect Jakarta-Bandung metropolitan areas will continue to grow which is marked by the increasing types of activities and public facilities from year to year. This trend will also have an impact on increasing the conversion of agricultural land to built-up land due to the phenomenon of urban sprawl from the central part of Karawang Regency in 
Murtadho, Pravitasari, Munibah, Rustiadi/ Jurnal Pembangunan Wilayah dan Kota, Vol.16, No.2, 2020, 102-111 Doi: https://doi.org/10.14710/pwk.v16i2.24883

various directions. For this reason, regional development in Karawang Regency must be more evenly distributed to all parts of the area in Karawang Regency so that development is not concentrated in only one part of the region and the possibility of agricultural land conversion will decrease.

\section{CONCLUSION}

Analysis of regional development in Karawang Regency shows that the distribution of the Village Development Index/ Indeks Perkembangan Desa (IPD) in 2014 has increased from 2003 as indicated by the increase in the number of villages with high and moderate classifications of IPD values. In 2014, villages with high classifications IPD values tended to be in villages in Karawang Barat, Karawang Timur, and Telukjambe Timur Sub-districts, as well as villages near the network roads that connecting Jakarta-Bandung metropolitan areas. Spatial distribution pattern analysis with Global Moran Index from the IPD values in 2003 and 2014 shows the presence of spatial autocorrelation with clustered distribution patterns. The results of the Local Moran Index analysis showed that the values of IPD in 2003 and 2014 had a clustered spatial distribution pattern in villages of Karawang Barat, Karawang Timur, and Telukjambe Timur Sub-districts as well as villages near the network roads that connecting Jakarta-Bandung metropolitan areas.

Research about regional development in Karawang Regency needs to be continued by analyzing the newest PODES data available, that is PODES of 2018 to see the Karawang Regency Development in 2018. It is also necessary to research the direction that must be done by Karawang Regency government or related stakeholders in addressing regional developments that occur in Karawang Regency especially villages near the network roads that connecting Jakarta-Bandung metropolitan areas.

\section{ACKNOWLEDGMENTS}

This research was a part of grand research of "Land Use Cover Changes and its Impacts in an Emerging Asian Megacity: the Case of Continuing Expanded Jakarta-Bandung Mega-Urban Region" (chaired by Dr. Ir. Ernan Rustiadi, M.Agr.), and funded by Ministry of Research, Technology and Higher Education (Kemenristekdikti).

\section{REFERENCES}

Abror, S. M., Purwoko, A., \& Pratomo, W. A. (2016). Analisis Pengaruh Pembangunan Jaringan Jalan terhadap Perubahan Guna Lahan di Kawasan Aek Kanopan. Jurnal Ekonom, 19 (2), 82-89.

Anselin, L. (1995). Local indicators of spatial association-LISA. Geographical Analysis, 27 (2), 93-115.

Anselin, L. (2005). Exploring Spatial Data with GeoDA ${ }^{T M}$ : A Workbook. Center for Spatially Integrated Social Science.

Dorodjatoen, A. M. H. (2009). The Emergence of Jakarta-Bandung Mega Urban Region and It's Future Challenges. Jurnal Perencanaan Wilayah dan Kota, 20 (1), 15-33.

Fotheringham, A. S. \& Rogerson, P. A. (1993). GIS and spatial analytical problems. INT. J. Geographical Information Systems, 7 (1), 3-19.

Giyarsih, S. R. (2012). Koridor Antar Kota sebagai Penentu Sinergisme Spasial: Kajian Geografi yang Semakin Penting. TATALOKA, 14 (2), 90-97.

Murtadho, A., Wulandari, S., Wahid, M., \& Rustiadi, E. (2018). Perkembangan wilayah dan perubahan tutupan lahan di Kabupaten Purwakarta sebagai dampak dari proses konurbasi Jakarta-Bandung. Journal of Regional and Rural Development Planning, 2 (2), 195-208.

Nainggolan, P. T. P. (2005). Analisis penentuan pusat-pusat pertumbuhan ekonomi di kabupaten simalungun. Jurnal Ekonomi dan Keuangan, 1 (12), 16-26.

Panuju, D. R. \& Rustiadi, E. (2010). Teknik Analisis Perencanaan Pengembangan Wilayah. Penuntun praktikum. Divisi Perencanaan Pengembangan Wilayah, Departemen Ilmu Tanah dan Sumberdaya Lahan, Fakultas Pertanian, IPB.

Pemerintah Kabupaten Karawang. (2016). Rencana Pembangunan Jangka Menengah Daerah Kabupaten Karawang tahun 2016-2021. Pemerintah Kabupaten Karawang.

Pemerintah Provinsi Jawa Barat. 2010. Peraturan Daerah Provinsi Jawa Barat No. 22 tahun 2010 tentang RTRWP Provinsi Jawa Barat tahun 2009-2029. Pemerintah Provinsi Jawa Barat. 
Murtadho, Pravitasari, Munibah, Rustiadi/ Jurnal Pembangunan Wilayah dan Kota, Vol.16, No.2, 2020, 102-111

Doi: https://doi.org/10.14710/pwk.v16i2.24883

Pemerintah Republik Indonesia. (2005). Peraturan Menteri Pekerjaan Umum No. 494 Tahun 2005 tentang Kebijakan dan Strategi Nasional Pengembangan Perkotaan. Sekretariat Negara.

Pravitasari, A. E., Saizen, I., Tsutsumida, N., \& Rustiadi, E. (2014). Detection of spatial clusters of flood-and landslide-prone areas using local moran index in Jabodetabek Metropolitan Area, Indonesia. International Journal of Ecology and Environmental Sciences, 40 (4), 233-243.

Pravitasari, A. E., Saizen, I., Tsutsumida, N., Rustiadi, E., \& Pribadi, D. O. (2015). Local Spatially Dependent Driving Forces of Urban Expansion in an Emerging Asian Megacity: the Case of Greater Jakarta (Jabodetabek). Journal of Sustainable Development, 8 (1), 108-119.

Pravitasari, A. E., Rustiadi, E., Mulya, S. P., Setiawan, Y., Fuadina, L. N., \& Murtadho, A. (2018). Identifying the Driving Forces of Urban Expansion and its Environmental Impact in Jakarta-Bandung Mega Urban Region. IOP Conference Series: Earth and Environmental Science, 149, 1-10.

Rustiadi, E., Saefulhakim, S., \& Panuju, D. R. (2018). Perencanaan dan Pengembangan Wilayah. Yayasan Pustaka Obor Indonesia.

Saifullah, K., Barus, B., \& Rustiadi, E. (2017). Spatial Modelling of Land Use/Cover Change (LUCC) in South Tangerang City, Banten. IOP Conf, 54 (1), 1-11.

Sitorus, S. R. P., Mulyani, M., \& Panuju, D. R. (2011). Konversi lahan pertanian dan keterkaitannya dengan kelas kemampuan lahan serta hirarki wilayah di Kabupaten Bandung Barat. Jurnal Tanah Lingkungan, 13 (2), 49-57.

Sitorus, S. R. P. (2017). Perencanaan Penggunaan Lahan. IPB Press.

Wong, D. W. S. \& Lee, J. (2005). Statistical Analysis of Geographic Information with ArcView GIS and ArcGIS. John Wiley \& Sons, Inc.

Wuryandari, T., Hoyyi, A., Kusumawardani, D. S., \& Rahmawati, D. (2014). Identifikasi autokorelasi spasial pada jumlah pengangguran di Jawa Tengah menggunakan Indeks Moran. Media Statistika, 7 (1), 1-10.

Yuriantari, N. P., Hayati, M. N., \& Wahyuningsih, S. (2017). Analisis autokorelasi spasial titik panas di Kalimantan Timur menggunakan Indeks Moran dan Local Indicator of Spatial Autocorrelation (LISA). Jurnal Eksponensial, 8 (1), 63-70. 